\title{
Dimethyl Carbonate as an Ambident Electrophile
}

\author{
Pietro Tundo,* Laura Rossi, ${ }^{\dagger}$ and Alessandro Loris \\ Dipartimento di Scienze Ambientali, Università Ca’ Foscari Venezia, Italy, and Consorzio \\ Interuniversitario Nazionale La Chimica per l'Ambiente, Italy, Dorsoduro 2137, 30123 Venezia, Italy \\ tundop@unive.it
}

Received August 20, 2004

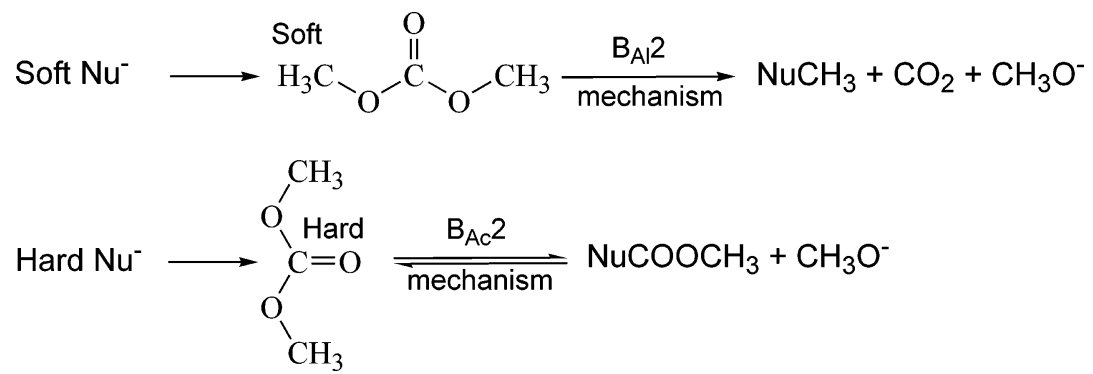

The features of various anions having different soft/hard character (aliphatic and aromatic amines, alcohoxydes, phenoxides, thiolates) are compared with regard to nucleophilic substitutions on dimethyl carbonate (DMC), using different reaction conditions. Results are well in agreement with the Hard-Soft Acid-Base (HSAB) theory. Accordingly, the high selectivity of monomethylation of $\mathrm{CH}_{2}$ acidic compounds and primary aromatic amines with DMC can be explained by two different subsequent reactions, which are due to the double electrophilic character of DMC. The first step consists of a hard-hard reaction and selectively produces a soft anion, which, in the second phase, selectively transforms into the final monomethylated product, via a soft-soft nucleophilic displacement (yield $>99 \%$ at complete conversion, using DMC as solvent).

\section{Introduction}

Dimethyl carbonate (DMC) is a well-known nontoxic reagent showing three main green-chemistry features (I, II, and III $)^{1 \mathrm{a}-\mathrm{d}}$ as compared to other carboxylating or alkylating agents (phosgene and methyl halides, respectively): $:^{2-\mathrm{d}}$

I. DMC does not produce inorganic salts in either acylation $^{3}$ (eq 1) or alkylation ${ }^{4 a, b}$ (eq 2) reactions:

\footnotetext{
* To whom correspondence should be addressed. Fax: +390412348620 .

$\dagger$ On leave from the Departamento de Química Orgánica, 5000 Cordoba, Argentina.

(1) (a) Tundo, P.; Anastas, P.; Black, D.; Breen, J.; Collins, T.; Memoli, S.; Miyamoto, J.; Polyakoff, M.; Tumas, W. Pure Appl. Chem. 2000, 72, 1207. (b) Anastas, P.; Warner, J. C. Green Chemistry: Theory and Practice; Oxford University Press: New York, 1998; p 30. (c) Sheldon, R. A. Pure Appl. Chem. 2000, 72, 1233. (d) Trost, B. M. Science 1991, 254, 1471

(2) (a) Rivetti, F. In Green Chemistry: Challenging Perspectives; Tundo, P., Anastas, P., Eds.; Oxford University Press: Oxford, 2000; p 201. (b) Delledonne, D.; Rivetti, F.; Romano, U. J. Organomet. Chem. 1995, 448, C15-C19. (c) Romano, U.; Rivetti, F.; Di Muzio, N., U.S. Patent 4,318,862, 1979. (d) Tundo, P. Continuous Flow Methods in Organic Synthesis; E. Horwood: Chichester, UK, 1991; Chapter 4, p 190.

(3) Mizia, F.; Rivetti, F.; Romano, U. EP 0570071, 1993.

(4) (a) Tundo, P.; Selva, M.; Bomben, A. Org. Synth. 1999, 76, 169
}

(b) Tundo, P.; Selva, M. Acc. Chem. Res. 2002, 35, 706.

$$
\begin{aligned}
& \mathrm{Y}^{-}+\mathrm{CH}_{3} \mathrm{OCOOCH}_{3} \rightleftharpoons \mathrm{Y}-\mathrm{COOCH}_{3}+\mathrm{CH}_{3} \mathrm{O}^{-} \\
& \mathrm{Y}^{-}+\mathrm{CH}_{3} \mathrm{OCOOCH}_{3}-\mathrm{Y}-\mathrm{CH}_{3}+\mathrm{CH}_{3} \mathrm{OCOO}^{-}
\end{aligned}
$$

In fact, since the leaving group, methyl carbonate, decomposes (eq 3), the base is restored and can be used in truly catalytic amounts. This feature allows utilization of continuous-flow (c-f) procedures (i.e. gas-liquid phasetransfer catalysis, GL-PTC, ${ }^{5 a, b}$ and continuously stirred tank reactor, $\mathrm{CSTR}^{6}$ ).

$$
\mathrm{CH}_{3} \mathrm{OCOO}^{-}-\mathrm{CH}_{3} \mathrm{O}^{-}+\mathrm{CO}_{2}
$$

II. Since reaction 1 is an equilibrium and reaction 2 is not, the product of the process can be controlled, temperature being the key factor. In fact, because methylation reactions involve higher Gibbs energies of activation, low temperatures allow carboxymethylation (DMC as phosgene substitutive), whereas high temperatures give

(5) (a) Tundo, P. J. Org. Chem. 1979, 44, 2048. (b) Tundo, P.; Selva, M. CHEMTECH 1995, 25, 31 .

(6) Bomben, A.; Selva, M.; Tundo, P.; Valli, L. Ind. Eng. Chem. Res. 1999, 38, 2075. 
TABLE 1. Monomethylation of Several $\mathrm{CH}_{2}$-Acidic Compounds

\begin{tabular}{clclrr}
\hline entry & \multicolumn{1}{c}{ substrate } & $T\left({ }^{\circ} \mathrm{C}\right)$ & \multicolumn{1}{c}{ product } & conversion $(\%)$ & selectivity $^{a}(\%)$ \\
\hline 1 & $\mathrm{PhCH}_{2} \mathrm{SO}_{2} \mathrm{Me}$ & 200 & $\mathrm{PhCH}(\mathrm{Me}) \mathrm{SO}_{2} \mathrm{Me}$ & 98 & 99 \\
2 & $\mathrm{PhOCH}_{2} \mathrm{COOH}$ & 200 & $\mathrm{PhOCH}(\mathrm{Me}) \mathrm{COOMe}$ & 100 & $8 \mathrm{c}$ \\
3 & $\mathrm{PhCH}_{2} \mathrm{CN}(\mathrm{GL}-\mathrm{PTC})$ & 180 & $\mathrm{PhCH}(\mathrm{Me}) \mathrm{CN}$ & 98 & 96 \\
4 & $\mathrm{PhCH}_{2} \mathrm{CN}$ (batch) & 180 & $\mathrm{PhCH}(\mathrm{Me}) \mathrm{CN}$ & 100 & 99 \\
\end{tabular}

${ }^{a}$ Selectivity is defined as monomethylated product/(monomethylated product + dimethylated product) $\times 100$.

methylation derivatives (DMC as a substitute of dimethyl sulfate, methyl chloride, etc.). ${ }^{7}$

Moreover, also operating at $200-250^{\circ} \mathrm{C}$, decomposition and polymerization products or tars are not formed and usually clear reaction mixtures are obtained.

III. DMC has a very selective behavior on alkylation of $\mathrm{CH}_{2}$ acidic compounds, as it yields the sole monomethyl derivative when reacting with arylacetonitriles, ${ }^{8 a}$ aryl acetates, ${ }^{8 \mathrm{a}}$ aryloxyacetic esters, ${ }^{8 \mathrm{~b}}$ sulfones, ${ }^{8 \mathrm{c}}$ sulfoxides, ${ }^{8 \mathrm{c}}$ and lactones. ${ }^{8 d}$ Regardless of the high temperature and the great excess of alkylating agent (DMC is also the solvent of the reactions), at complete conversion of the substrate selectivity for the monomethylated product is often $>99 \%$. One can maintain that high pressures and high temperatures are not suitable for green chemistry; our opinion is that technology is not limited by green chemistry, which, vice versa, utilizes the best available tools.

Table 1 reports the selectivity in the monomethylation of some $\mathrm{CH}_{2}$ acidic compounds. Reaction 4 , for example, refers to monoalkylation of nitriles, esters, and sulfones:

$$
\begin{gathered}
\underset{\mathbf{1}}{\mathrm{ArCH}_{2} \mathrm{X}}+\underset{\mathbf{C H}}{\mathrm{CH}_{3} \mathrm{OCOOCH}_{3}} \stackrel{\mathrm{K}_{2} \mathrm{CO}_{3}, 180^{\circ} \mathrm{C}}{\mathrm{ArCH}\left(\mathrm{CH}_{3}\right) \mathrm{X}+\mathrm{CO}_{2}}+\mathrm{CH}_{3} \mathrm{OH} \\
\mathrm{X}=\mathrm{CN}, \mathrm{COOCH}_{3}, \mathrm{SO}_{2} \mathrm{R}, \mathrm{SO}_{2} \mathrm{Ar}
\end{gathered}
$$

This reaction has an industrial relevance, since $\mathrm{ArCH}-$ $\left(\mathrm{CH}_{3}\right) \mathrm{COOH}$ are well know anti-inflammatory agents. ${ }^{8 \mathrm{a}}$

We also reported about primary aromatic amines (aniline, $o$-toluidine, $o$ - and $p$-chloroaniline) undergoing $\mathrm{N}$-methylation in c-f conditions. $\mathrm{N}$-Methyl anilines and their urethanes were continuously collected at the end of a plug-flow reactor ${ }^{9}$ (eq 5), whereas $N, N$-dimethylated products were present in trace amounts only.

$$
\begin{aligned}
& \mathrm{ArNH}_{2}+\mathrm{CH}_{3} \mathrm{OCOOCH}_{3} \frac{\mathrm{GL}-\mathrm{PTC}}{\mathrm{K}_{2} \mathrm{CO}_{3}, \mathrm{PEG}, 180^{\circ} \mathrm{C}} \\
& \mathrm{ArNHCH}_{3}+\mathrm{ArN}\left(\mathrm{CH}_{3}\right) \mathrm{COOCH}_{3}
\end{aligned}
$$

$\mathrm{ArNH}_{2}=$ aniline, $o$-toluidine, $o$-chloroaniline,

$$
p \text {-chloroaniline; } \mathrm{PEG}=\text { poly(ethyleneglycols) }
$$

Differently, under GL-PTC conditions, aliphatic amines give both mono- and dialkylated compounds, without

(7) Tundo, P.; Selva, M.; Perosa, A.; Memoli, S. J. Org. Chem. 2002, 67, 1071.

(8) (a) Selva, M.; Marques, C. A.; Tundo, P. J. Chem. Soc., Perkin Trans. 1 1994, 1323. Loosen, P.; Tundo, P.; Selva, M., U.S. Patent 5,278,533, 1994. (b) Bomben, A.; Marques, C. A.; Selva, M.; Tundo, P. Tetrahedron 1995, 51, 11573. (c) Bomben, A.; Selva, M.; Tundo, P. J. Chem. Res., Synop. 1997, 448. (d) Tundo, P.; Trotta, F.; Moraglio, G. Italian Pat. 20159A/90C, 1990.

(9) Trotta, F.; Tundo, P.; Moraglio, G. J. Org. Chem. 1987, 52, 1300. appreciable selectivity (unpublished results from our laboratory).

The reactions of amines with DMC also have a great industrial interest (e.g., synthesis of isocyanates without utilization of phosgene).

While features I and II are easily accountable, the reasons for the selectivity in monomethylation are not immediately evident. Isolation of intermediates and a detailed kinetic study showed $\mathrm{us}^{7,8 a}$ that the reaction mechanism does not imply a simple nucleophilic substitution (eq 6).

$$
\begin{aligned}
& \underset{\mathbf{1}^{-}}{\mathrm{ArCH}^{-} \mathrm{X}}+\mathrm{CH}_{3} \mathrm{OCOOCH}_{3} \\
& \underset{\mathbf{4}}{\mathrm{ArCH}\left(\mathrm{CH}_{3}\right) \mathrm{X}}+\mathrm{CH}_{3} \mathrm{OCOO}^{-}
\end{aligned}
$$

Actually, monomethylation derives from an unusual reaction pathway that involves the reactivity of anion $\mathbf{1}^{-}$ and anion $\mathbf{2}^{-}$, according to two consecutive nucleophilic displacements: the first one follows a $\mathrm{B}_{\mathrm{Ac}} 2$ mechanism, while the second occurs through a $\mathrm{B}_{\mathrm{Al}} 2$ mechanism (eqs 7 and 8, respectively):

$$
\begin{aligned}
& \mathrm{ArCH}^{-} \mathrm{X}+\mathrm{CH}_{3} \mathrm{OCOOCH}_{3} \rightarrow \\
& \mathbf{1}^{-} \\
& \underset{2}{\operatorname{ArCH}\left(\mathrm{COOCH}_{3}\right) \mathrm{X}}+\mathrm{CH}_{3} \mathrm{O}^{-} \quad\left(7, \mathrm{~B}_{\mathrm{Ac}} 2\right) \\
& \operatorname{ArC}^{-}\left(\mathrm{COOCH}_{3}\right) \mathrm{X}+\mathrm{CH}_{3} \mathrm{OCOOCH}_{3} \rightarrow \\
& 2^{-} \\
& \operatorname{ArC}\left(\mathrm{CH}_{3}\right)\left(\mathrm{COOCH}_{3}\right) \mathrm{X}+\mathrm{CH}_{3} \mathrm{OCOO}^{-} \quad\left(8, \mathrm{~B}_{\mathrm{Al}} 2\right)
\end{aligned}
$$

Accordingly, $\mathbf{4}$ is produced through a series of consecutive pathways, all of them being very selective.

Scheme 1 accounts for such a behavior: the reaction proceeds through the carboxymethylation species (step b), which afterward reacts with the methyl of DMC (step e; this step pushes the reaction to the end). The overall reaction of Scheme 1 is that shown in eq 4 .

In summary, while anion $\mathrm{ArCH}^{-} \mathrm{X}$ does not give $\mathrm{ArC}\left(\mathrm{CH}_{3}\right)_{2} \mathrm{X}$, also anion $\mathrm{ArC}-\left(\mathrm{COOCH}_{3}\right) \mathrm{X}$ does not allow the formation of $\mathrm{ArC}\left(\mathrm{COOCH}_{3}\right)_{2} \mathrm{X}$.

In this paper we report how the different reactivity of DMC in eqs 7 and 8 may be rationalized by the Hard-Soft Acid and Base (HSAB) theory.

\section{Results}

According to the HSAB theory, first introduced by Pearson in $1963^{10,11}$ and further developed by Mèndez, ${ }^{12}$

(10) Pearson, R. G. J. Am. Chem. Soc. 1963, 85, 3533.

(11) Pearson, R. G.; Songstad, J. J. Am. Chem. Soc. 1967, 89, 1827. 
SCHEME 1. Reaction Pathway for the Monomethylation of $\mathrm{CH}_{2}$-Acidic Compounds $\left(\mathrm{X}=\mathrm{CN}, \mathrm{CO}_{2} \mathrm{CH}_{3}\right)$ with DMC

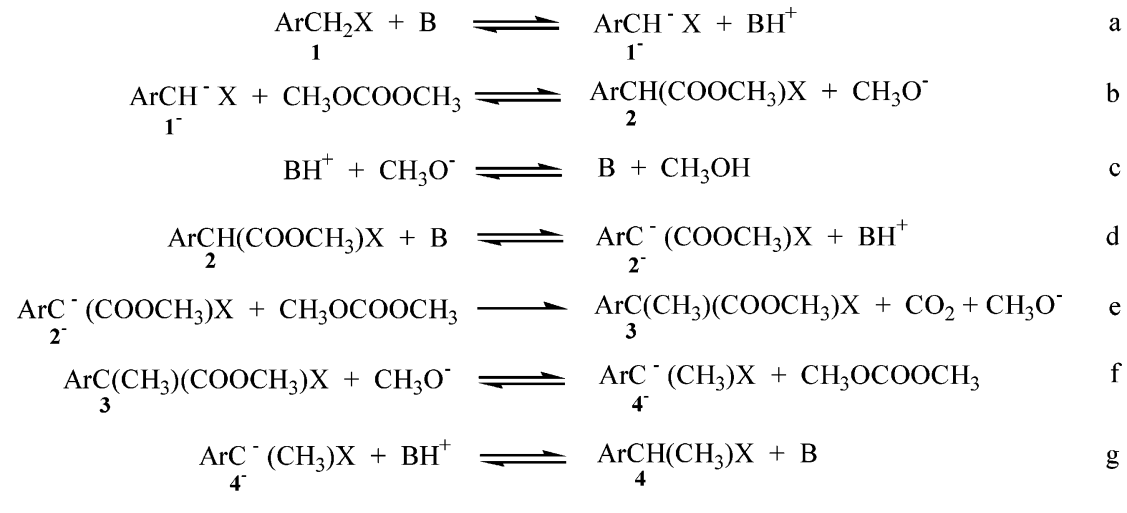

Overall reaction $\mathrm{ArCH}_{2} \mathrm{X}+\mathrm{CH}_{3} \mathrm{OCOOCH}_{3}$ 1

SCHEME 2. DMC as Ambident Nucleophile

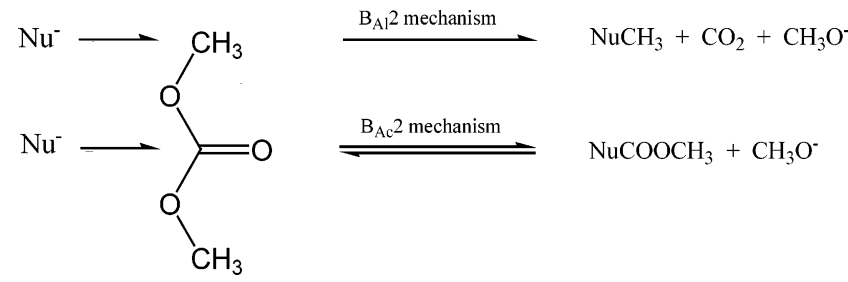

softer nucleophiles react with softer centers, whereas hard nucleophiles preferably react with hard electrophiles. ${ }^{13}$ Some fundamental studies about this behavior were performed by Klopman. ${ }^{14,15}$

DMC has three reactive centers that can interact with nucleophiles: the carbonyl, and two methyl groups (Scheme 2). Such centers can be classified according to the HSBA principle: the carbonyl group is the harder electrophile, as a result of its polarized positive charge and $\mathrm{sp}^{2}$ hybridization; the two methyl groups represent softer electrophiles, thanks to their $\mathrm{sp}^{3}$ orbital and their saturated carbon atom, which has a weaker positive charge.

Many ambident nucleophiles are known, but few ambident electrophiles have been studied. Many investigations verified the compliance of reactivity of ambident nucleophiles and electrophiles with the HSAB theory.

Among the ambident electrophiles we can mention esters and particularly propiolactones $,{ }^{16 \mathrm{a}-\mathrm{d}} \alpha, \beta$-unsaturated carbonyls, ${ }^{17} 3$-chloro-1,2-benzoisothiazol, ${ }^{18}$ and tricholocarbonates. ${ }^{19}$ Actually, also alkyl halides are in-

(12) Gazquez, J. L.; Mèndez, F. J. J. Phys. Chem. 1994, 98, 4049.

(13) Tse-Lok, H. Chem. Rev. 1975, 75, 1.

(14) Chemical Reactivity and Reaction Paths; Klopman, G., Ed.; Wiley: New York, 1974

(15) Klopman, G. J. Am. Chem. Soc. 1968, 90, 223.

(16) (a) Gresham, T. L.; Jansen, J. E.; Shaver, F. W.; Gregory, J. T.; Beears, W. L. J. Am. Chem. Soc. 1948, 70, 1004. (b) Gresham, T. L.; Jansen, J. E.; Shaver, F. W.; Frederick, M. R.; Fiedorek, F. T.; Bankert, R. A.; Gregory, J. T.; Beears, W. L. J. Am. Chem. Soc. 1952 74, 1323. (c) Gresham, T. L.; Jansen, J. E.; Shaver, F. W.; Gregory, J. T. J. Am. Chem. Soc. 1948, 70, 999. (d) Gresham, T. L.; Jansen, J. E.; Shaver, F. W.; Bankert, R. A. J. Am. Chem. Soc. 1949, 71, 661.

(17) Davidson, R. S.; Gunther, W. H. H.; Waddington-Feather, S. M.; Lythgoe, B. J. Chem. Soc. 1964, 4907.

(18) Carrington, D. E. L.; Clarke, K.; Scrowston, R. M. J. Chem. Soc. C 1971, 3262.

(19) Pierce, A. C.; Joulliè, M. M. J. Org. Chem. 1962, 27, 3968. cluded among the ambident electrophiles, as they react with nucleophiles, yielding either products of substitution reactions (soft-soft reaction) or alkenes (hard-hard interaction). ${ }^{20 \mathrm{a}, \mathrm{b}}$ At this regard, the reaction of 2-bromoethylarenes with different phenoxide anions is relevant: it yields different mixtures of ethers and alkenes, according to the nucleophilic nature of the anion species which can modulate the reaction outcome. ${ }^{21}$

Here the reactivity of some soft/hard nucleophiles with DMC is compared: both nucleophiles at nitrogen, oxygen, and sulfur are considered. According to their nature, nucleophiles can discriminate between the carbon atoms of DMC. Some reactions have been already observed, while others are here reported for the first time.

Nitrogen Nucleophiles. In the absence of a base, aliphatic amines such as benzylamine react with DMC to give both alkylation and carboxymethylation products, without any selectivity (entry 1, Table 2 and Scheme 3); both $\mathrm{B}_{\mathrm{Ac}} 2$ and $\mathrm{B}_{\mathrm{Al}} 2$ mechanisms are followed. The newly formed carbamate does not undergo methylation reaction if a base is not present.

In the presence of a base, aliphatic and aromatic amines yield carbamate only; carboxymethylation reaction on benzylamine occurs quantitatively, with $100 \%$ selectivity, in few minutes (entries 2 and 4, Table 2). Afterward, the already formed carbamate gives off its $N$-methyl derivative (entry 3 and 5). Scheme 4 outlines this behavior. Double carboxymethylation (i.e., $\left.\mathrm{PhCH}_{2} \mathrm{~N}\left(\mathrm{COOCH}_{3}\right)_{2}\right)$ was never observed under such conditions.

Aromatic amines (aniline, entry 6, Table 2) are less reactive, as in the absence of a base they do not react at the reflux temperature of DMC $\left(90^{\circ} \mathrm{C}\right)$. As reported in Experimental Section, aniline was transformed in the absence of a base at $200{ }^{\circ} \mathrm{C}$ in an autoclave with DMC as solvent; after $24 \mathrm{~h}$ the conversion was $61 \%$ without selectivity: $15 \%$ monomethylation product, $37 \%$ dimethylated product, and $9 \%$ carbamate were observed.

In contrast, with $\mathrm{K}_{2} \mathrm{CO}_{3}$ as a catalyst and under GL-PTC conditions, monomethylation was reported to

(20) (a) Bordwell, F. G. Organic Chemistry; Macmillan: New York 1963; p 218. (b) Parke, A. J. Adv. Phys. Org. Chem. 1967, 5, 173.

(21) Hudson, R. F.; Klopman, G. J. Chem. Soc. 1964, 5. 
TABLE 2. Reaction of Amines with DMC in the Presence and Absence of Bases ${ }^{a}$

\begin{tabular}{|c|c|c|c|c|c|c|c|}
\hline entry & amine & base & time $(\min )$ & $\% \mathrm{MNM}$ & $\% \mathrm{DNM}$ & $\%$ carbamate & $\%$ NMcarbamate \\
\hline 1 & benzylamine & & 360 & 12 & 6 & 4 & \\
\hline 2 & & $\mathrm{CH}_{3} \mathrm{ONa}$ & 9 & & & 95 & 0.5 \\
\hline 3 & & $\mathrm{CH}_{3} \mathrm{ONa}$ & 180 & & & 46 & 54 \\
\hline 4 & & $\left(\mathrm{CH}_{3}\right)_{3} \mathrm{COK}$ & 1 & & & 100 & \\
\hline 5 & & $\left(\mathrm{CH}_{3}\right)_{3} \mathrm{COK}$ & 30 & & & 32 & 68 \\
\hline 6 & aniline & & 360 & $\mathrm{nr}$ & & & \\
\hline 7 & & $\mathrm{CH}_{3} \mathrm{ONa}$ & 210 & & & 67 & 2 \\
\hline 8 & & $\left(\mathrm{CH}_{3}\right)_{3} \mathrm{COK}$ & 1 & & & 100 & \\
\hline 9 & & $\left(\mathrm{CH}_{3}\right)_{3} \mathrm{COK}$ & 180 & & & 60 & 40 \\
\hline 10 & 1-decylamine & $\mathrm{CH}_{3} \mathrm{ONa}$ & 8 & & & 94 & \\
\hline 11 & & $\mathrm{CH}_{3} \mathrm{ONa}$ & 360 & & & 22 & 78 \\
\hline 12 & & $\left(\mathrm{CH}_{3}\right)_{3} \mathrm{COK}$ & 1 & & & 100 & \\
\hline 13 & & $\left(\mathrm{CH}_{3}\right)_{3} \mathrm{COK}$ & 60 & & & 56 & 44 \\
\hline 14 & 1,6 -hexanediamine & $\mathrm{CH}_{3} \mathrm{ONa}$ & 30 & & & 100 & \\
\hline
\end{tabular}

${ }^{a} \mathrm{DMC}$ reflux temperature, $90^{\circ} \mathrm{C}$; molar ratio amine/DMC/base $=1.0 / 40 / 1.2 . \mathrm{MNM}=$ mono $N$-methylation; $\mathrm{DNM}=$ di $N$-methylation; NMcarbamate $=N$-methyl carbamate. See Experimental Section.

\section{SCHEME 3. Reaction of Benzylamine with DMC in the Absence of a Base}

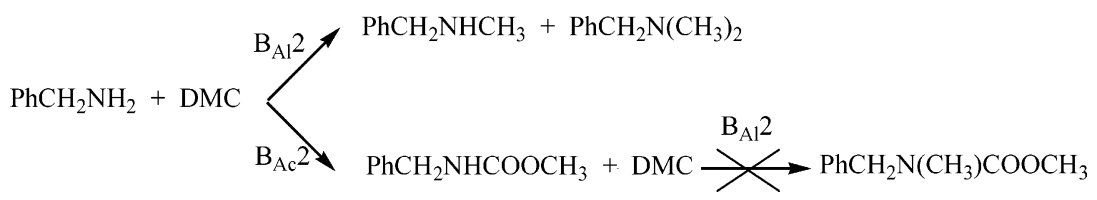

SCHEME 4. Reactions of Benzylamine with DMC in the Presence of a Base

$$
\begin{gathered}
\mathrm{PhCH}_{2} \mathrm{NH}_{2}+\mathrm{CH}_{3} \mathrm{OCOOCH}_{3} \stackrel{\text { base }}{\longrightarrow} \mathrm{PhCH}_{2} \mathrm{NHCOOCH}_{3}+\mathrm{CH}_{3} \mathrm{OH} \\
\mathrm{PhCH}_{2} \mathrm{NHCOOCH}_{3}+\mathrm{CH}_{3} \mathrm{OCOOCH}_{3} \stackrel{\text { base }}{\longrightarrow} \mathrm{PhCH}_{2} \mathrm{~N}_{\left(\mathrm{CH}_{3}\right) \mathrm{COOCH}_{3}+\mathrm{CO}_{2}+\mathrm{CH}_{3} \mathrm{OH}}
\end{gathered}
$$

occur selectively. ${ }^{5}$ Although more slowly, aromatic amines in the presence of a base (entries 7-9, Table 2) follow the behavior of aliphatic ones reported in Scheme 4.

Oxygen Nucleophiles. Alcohols give only transesterification products with DMC (eq 9),

$$
\mathrm{ROH}+\mathrm{CH}_{3} \mathrm{OCOOCH}_{3} \stackrel{\mathrm{PEG}, \mathrm{K}_{2} \mathrm{CO}_{3}}{\underset{\mathrm{ROCOOCH}_{3}}{\rightleftharpoons}}
$$

either under GL-PTC at $180{ }^{\circ} \mathrm{C}^{22}$ or under batch conditions. Also, operating at $200{ }^{\circ} \mathrm{C}$ the reaction occurs at the carbonyl atom only: when 1-octanol was used in reactions with $\mathrm{DMC}$ in the presence of $\mathrm{K}_{2} \mathrm{CO}_{3},{ }^{23}$ no methyl ether was observed, but methyl octyl carbonate and dioctyl carbonate were the only products. Methylation of alcohols was reported to occur operating in the presence of tertiary amines ${ }^{24}$ ((dimethylamino)pyridine, 1,4-diazobicyclo[2,2,2] octane). In this case, however, the catalyst modifies the hard-soft character of the two centers, thus allowing the nucleophilic displacement by the alcoxide to occur.

$p$-Substituted phenols were used in reactions with DMC at its reflux temperature in the presence of $\mathrm{K}_{2} \mathrm{CO}_{3}$. Under such conditions the softer phenoxide anions could discriminate between the two centers of DMC and their substituent controlled the reaction outcome.

(22) Tundo, P.; Trotta, F.; Moraglio, G.; Logorati, F. Ind. Eng. Chem Res. 1988, 27, 1565 .

(23) 1-Octanol $(9.3 \mathrm{mmol})$ was reacted in an autoclave with $40 \mathrm{~mL}$ of $\mathrm{DMC}$ (solvent and reactant) in the presence of $11 \mathrm{mmol}$ of $\mathrm{K}_{2} \mathrm{CO}_{3}$, at $200{ }^{\circ} \mathrm{C}$.

\begin{tabular}{|c|c|c|c|c|}
\hline entry & phenol & $\begin{array}{c}\% \\
\text { conversion }\end{array}$ & $\begin{array}{c}\% \\
\text { methylation }\end{array}$ & $\begin{array}{l}\% \text { carboxy- } \\
\text { methylation }\end{array}$ \\
\hline 1 & $p$-methoxyphenol & 7.0 & 23 & 77 \\
\hline 2 & $p$-cresol & 36.3 & 39 & 61 \\
\hline 3 & phenol & 27.7 & 72 & 28 \\
\hline 4 & $p$-chorophenol & 62.0 & 98 & 2 \\
\hline 5 & $p$-cyanophenol ${ }^{b}$ & 100 & 100 & \\
\hline
\end{tabular}

(24) Greenshields, J. N. U. S. Patent 4,770,871, 1988.
TABLE 3. Reaction of Phenols with DMC in the Presence of $\mathrm{K}_{2} \mathrm{CO}_{3}{ }^{a}$

${ }^{a} \mathrm{DMC}$ reflux temperature, $90{ }^{\circ} \mathrm{C}$; molar ratio phenol/DMC/ $\mathrm{K}_{2} \mathrm{CO}_{3}=1.0 / 40 / 1.2$. Conversions after $53 \mathrm{~h} .{ }^{b}$ After $30 \mathrm{~h}$, conversion $82 \%$ in the methylated derivative only. See Exp. Section.

Table 3 reports the results and clearly shows that phenoxides undergo nucleophilic substitution on either the methyl or the carbonyl group (eqs 10 and 11, respectively). The substituent on the aromatic ring clearly influences the reactivity: softer phenoxide anions give $\mathrm{S}_{\mathrm{N}} 2$ displacement only, while harder ones allow both $\mathrm{B}_{\mathrm{Ac}} 2$ and $\mathrm{B}_{\mathrm{Al}} 2$ reactions.

$$
\begin{array}{r}
\mathrm{ArOH}+\mathrm{CH}_{3} \mathrm{OCOOCH}_{3} \stackrel{\mathrm{K}_{2} \mathrm{CO}_{3}}{\mathrm{ArOCH}_{3}}+\mathrm{CO}_{2}+\mathrm{CH}_{3} \mathrm{OH} \\
\mathrm{ArOH}+\mathrm{CH}_{3} \mathrm{OCOOCH}_{3} \stackrel{\mathrm{K}_{2} \mathrm{CO}_{3}}{\rightleftharpoons} \\
\mathrm{ArOCOOCH}_{3}+\mathrm{CH}_{3} \mathrm{OH}
\end{array}
$$

Sulfur Nucleophiles. Aliphatic and aromatic thiols were reacted with DMC under comparable conditions: the results reported in Table 4 show that they produce only the methylated derivatives (eq 12): both 1-octanthiol 
TABLE 4. Reaction of Thiols and 1-Octanol with DMC in the Presence and Absence of $\mathrm{K}_{2} \mathrm{CO}_{3}{ }^{a}$

\begin{tabular}{rlrrcc}
\hline entry & \multicolumn{1}{c}{ thiol } & base & $\begin{array}{c}\text { time } \\
(\mathrm{h})\end{array}$ & $\begin{array}{c}\% \\
\text { methylation }\end{array}$ & $\begin{array}{c}\% \text { carboxy- } \\
\text { methylation }\end{array}$ \\
\hline 1 & thiophenol & & 1 & 27 & \\
2 & thiophenol & $\mathrm{K}_{2} \mathrm{CO}_{3}$ & 4 & 100 & \\
3 & 1-octanthiol & $\mathrm{K}_{2} \mathrm{CO}_{3}$ & 24 & 34 & 65 \\
4 & 1-octanol & $\mathrm{K}_{2} \mathrm{CO}_{3}$ & 7 & & 6 \\
\multicolumn{4}{c}{${ }^{a}$ DMC reflux temperature, $90{ }^{\circ} \mathrm{C}$; molar ratio thiol/DMC/ $/ \mathrm{K}_{2} \mathrm{CO}_{3}$} \\
$=1.0 / 40 / 1.2$ See Experimental Section.
\end{tabular}

and thiophenol (entry 2 and 3) attack the methyl group.

$$
\mathrm{RSH}+\mathrm{CH}_{3} \mathrm{OCOOCH}_{3} \rightarrow \mathrm{RSCH}_{3}+\mathrm{CO}_{2}+\mathrm{CH}_{3} \mathrm{OH}
$$

Since the sulfur nucleophiles are very reactive, thiophenol was able to react in the absence of a base as well (entry 1), giving thioanisole. To rule completely out $\mathrm{RSCOOCH}_{3}$ as a possible intermediate in the reaction, $n-\mathrm{C}_{8} \mathrm{H}_{17} \mathrm{SCOOCH}_{3}$ was refluxed with DMC in the absence of potassium carbonate (eq 13): no reaction was observed after $24 \mathrm{~h}$, showing that $\mathrm{RSCOOCH}_{3}$ is not an intermediate in methylation reactions with thiolates (see Experimental Section).

$$
\mathrm{RSCOOCH}_{3}+\mathrm{CH}_{3} \mathrm{OCOOCH}_{3} \rightarrow \text { No reaction }
$$

\section{Discussion}

The results here reported are in good agreement with the reactivity of ambident electrophiles with soft/hard nucleophiles, according to the HSAB theory.

Nitrogen Nucleophiles. It is well-known that bases significantly accelerate aminolysis and transamination reactions. Bunnett ${ }^{25}$ suggested that the direct participation of a base was the reason for the enhanced reactivity of nitrogen nucleophiles with the carbonyl. In accordance with other authors, ${ }^{26}$ naked $\mathrm{RNH}^{-}$is excluded from the mechanism; it looks like the role of the base is that of removing $\mathrm{H}^{+}$from protonated nitrogen during or after the attack, increasing in any case the negative charge on nitrogen atom. Whatever the exact mechanism may be, the presence of a base enhances the hardness of the nucleophile. So, the reactivity with harder electrophiles (the carbonyl in this case) is raised and aminolysis reactions are highly favored.

DMC represents a valid model molecule; its reactivity can explain the competition between the harder $\mathrm{RNH}^{-}$ (more or less naked) and the softer $\mathrm{RNH}_{2}$, through the HSAB theory. The behavior of amines in the presence and in the absence of a base reported in Table 2 confirms that since the hardness of the nucleophile is increased while operating in the presence of a base, the $\mathrm{B}_{\mathrm{Ac}} 2$ rate is dramatically accelerated and carboxymethyl derivatives are selectively obtained. Once formed, the urethans need the presence of a base to further react with DMC. In these conditions, their $\mathrm{RN}^{-} \mathrm{COOCH}_{3}$ anions, softer nucleophiles than $\mathrm{RNH}^{-}$, undergo solely $\mathrm{B}_{\mathrm{Al}} 2$ reactions. This was proved by the fact that no $\mathrm{RN}\left(\mathrm{COOCH}_{3}\right)_{2}$ products, deriving from a $\mathrm{B}_{\mathrm{Ac}} 2$ reaction mechanism, were observed during our experiments.

(25) Bunnett, J. F.; Davis, G. T. J. Am. Chem. Soc. 1960, 82, 665

(26) Jencks, W. P.; Carriuolo, J. J. Am. Chem. Soc. 1960, 82, 675.
Oxygen and Sulfur Nucleophiles. Alcohols and Thiols. It is well established that sulfur and oxygen anions behave in an opposite way with electrophilic centers during nucleophilic substitutions. ${ }^{27} \mathrm{We}$ studied these reactions and found a further confirmation. The comparison of the reactivity of 1-octanthiol and 1-octanol with DMC (entries 3 and 4, Table 4) outlines the difference in chemoselectivity of $\mathrm{RS}^{-}$and $\mathrm{RO}^{-}$anions, due to their diverse hardness. Under all of the investigated conditions, alkoxides show a $\mathrm{B}_{\mathrm{Ac}} 2$ reaction mechanism, differently from thiolates, which react via a $\mathrm{B}_{\mathrm{Al}} 2$ type.

Phenols. Due to their delocalized anion, phenoxides are softer nucleophilic species than alkoxides. Such feature can be influenced by the substituent. Their reactivity with DMC (Table 3) fits well with the HSAB theory and with what is already reported about the soft/ hard character of such anions, in relation to the carboxymethyl/methyl competition during reactions with 2-bromoethylbenzene. ${ }^{21}$

\section{Conclusions}

$\mathrm{CH}_{2}$ Acidic Compounds and Primary Amines. By comparing the here described results for nitrogen, oxygen, and sulfur nucleophiles, we can assert that anions $\mathbf{1}^{-}$and $\mathbf{2}^{-}$give different compounds since they have different soft/hard character. Their difference in hardness provides a reason for the discrimination observed between the two electrophilic centers of DMC.

The hard nucleophile $\mathbf{1}^{-}$first attacks only the carbonyl of DMC (eq 7); the anion of the product $\mathbf{2}^{-}$is a softer nucleophile and selectively produces the methyl derivative (eq 8).

The change in hardness/softness of the anion, due to the presence of the carboxymethyl group, is enough to significantly alter the reactivity of the DMC molecule.

Primary amines behave similarly. In the presence of a base, which exalts the hard nature of the nucleophile, both aliphatic and aromatic derivatives first react according a $\mathrm{B}_{\mathrm{Ac}} 2$ mechanism, so producing a softer anion. In its turn, the latter reacts via a soft/soft interaction.

In the absence of a base, both $\mathrm{B}_{\mathrm{Ac}} 2$ and $\mathrm{B}_{\mathrm{Al}} 2$ mechanisms occur simultaneously, although aliphatic amines are of course more reactive.

The combination of the dual electrophilic character of DMC with its reaction products allows two consecutive steps to occur in a selective way for what concerns both reaction sequence and yields: first the hard-hard reaction occurs and produces a soft anion only; then a softsoft nucleophilic displacement leads to the final product. Since hard-soft and soft-hard interactions are inhibited, neither double methylation nor double carboxymethylation occur.

\section{Experimental Section}

All compounds used were ACS grade and were employed without further purification.

GC analyses were performed using a $30 \mathrm{~m}$, CP-sil $24 \mathrm{CB}$ capillary column. GC-MS analyses were performed on a mass detector at $70 \mathrm{eV}$ coupled to a gas chromatograph fitted with

(27) Rahmathullah, S.; Hall, J. E.; Bender, B. C.; McCurdy, D. R. Tidwell, R. R.; Boykin, D. W. J. Med. Chem. 1999, 42, 3994. 
a $30 \mathrm{~m}$, HP 5 capillary column. Reaction mixtures were compared with authentic commercial samples.

All reactions were carried out in a three-necked, 100-mL round-bottomed flask with a reflux condenser and a magnetic bar.

Reaction of DMC with Amines in the Presence of Bases (Table 2). The base (sodium methylate or potassium tert-butoxide) and DMC were charged together in the reaction flask. The amine $\left(9.3 \times 10^{-3} \mathrm{~mol}\right.$; benzylamine, aniline, 1-decylamine, and 1,6-hexanediamine) was added at reflux temperature $\left(90{ }^{\circ} \mathrm{C}\right)$. Amine, base, and DMC were used in a 1.0/1.2/40 molar ratio, respectively.

Nitrogen gas was flowed to remove the $\mathrm{CO}_{2}$ that possibly formed as a byproduct. Samples $(0.5 \mathrm{~mL})$ were withdrawn periodically and treated with $1.0 \mathrm{~mL}$ of water and $1.0 \mathrm{~mL}$ of diethyl ether. The organic phase was analyzed by GC and GC-MS

Reaction of DMC with Benzylamine in the Absence of Base (Table 2, Entry 1). Benzylamine $\left(9.3 \times 10^{-3} \mathrm{~mol}\right)$ was reacted with $\mathrm{DMC}$ in a 1.0/40 molar ratio at reflux temperature for $6 \mathrm{~h}$.

Reactions of DMC with Aniline in the Absence of Base (Table 2, Entry 6 and Text). Aniline $\left(9.3 \times 10^{-3} \mathrm{~mol}\right)$ was reacted with DMC in a 1.0/40 molar ratio both at reflux temperature for $6.0 \mathrm{~h}$ and at $200{ }^{\circ} \mathrm{C}$ (thermostated stainless autoclave) for $24 \mathrm{~h}$.

Reaction of DMC with Phenols (Table 3). The same procedure described above was followed for the reactions of phenols. Phenols $\left(9.3 \times 10^{-3} \mathrm{~mol}, p\right.$-methoxyphenol, $p$-cresol, phenol, $p$-chlorophenol, and $p$-cyanophenol) were refluxed under stirring with $\mathrm{DMC}$ and $\mathrm{K}_{2} \mathrm{CO}_{3}$. Molar ratio phenol/ $\mathrm{K}_{2} \mathrm{CO}_{3} / \mathrm{DMC}$ was $1.0 / 1.2 / 40$, respectively.

Reaction of DMC with Thiols (Table 4). The same procedure described above was followed for the reactions of thiols. Thiols $\left(9.3 \times 10^{-3} \mathrm{~mol}\right.$, thiophenol and 1-octanthiol $)$ were refluxed under stirring with $\mathrm{DMC}$ and $\mathrm{K}_{2} \mathrm{CO}_{3}$. Molar ratio thiol/ $\mathrm{K}_{2} \mathrm{CO}_{3} / \mathrm{DMC}$ was $1.0 / 1.2 / 40$, respectively. Thiophenol was reacted with $\mathrm{DMC}$ in the same molar ratio and at the same temperature also in the absence of base (entry 1 ). The reaction of 1-octanol with DMC (entry 4) was carried out in the same conditions.

Reaction of $\boldsymbol{n}$-Octanethiomethylester with DMC (eq 13). The title compound $(1.5 \mathrm{mmol})$ was refluxed in DMC (1.0/40 molar ratio, respectively) in a two-necked, $50-\mathrm{mL}$ round-bottomed flask with a reflux condenser and a magnetic bar. No reaction was observed after $24 \mathrm{~h}$.

Acknowledgment. Contributions from the Consorzio Interuniversitario Nazionale "La Chimica per l'Ambiente", INCA (Interuniversity National Consortium "Chemistry for the Environment"), and Italian Ministry for Foreign Affairs, Ufficio V, are gratefully acknowledged.

JO048532B 